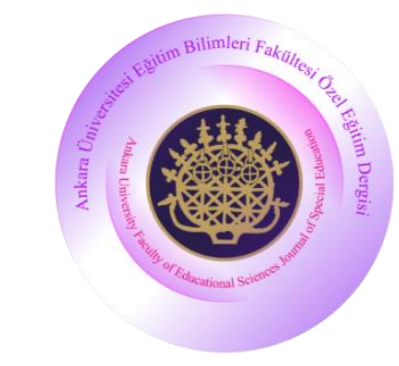

\section{Ankara University Faculty of Educational Sciences Journal of Special Education}

Year: 2020, Volume: 21, No: 2, Page No: 227-246

doi: 10.21565/ozelegitimdergisi.513953

\title{
Level of Awareness of Autism Spectrum Disorder among Members of Saudi Society: An Exploratory Study
}

\author{
Ola M. Abusukkar \\ Princess Nourah Bint Abdulrahman University
}

\begin{abstract}
The study aimed at identifying the level of awareness of autism spectrum disorder (ASD) among Saudi society members. The author adopted the analytical descriptive approach and prepared a scale for measuring the level of ASD awareness. The sample consisted of 888 Saudis comprising 174 males and 714 females, aged 18 to 58 years old. Results showed that a total of 55.2\% of the participants has no information about ASD and mass media represents the main source of information for $56.8 \%$ of them. There are no statistically significant differences in ASD awareness levels among participants from different districts. There are statistically significant differences in the level of ASD awareness between male and female participants, favoring females, and between young and old participants, favoring young. The highest ASD awareness level was among Ph.D. holders, and the lowest was among holders of moderate and lower qualifications. In regard of profession, the highest ASD awareness level was among practitioners of Special Education and the lowest was among the unemployed.
\end{abstract}

Keywords: Autism spectrum disorder, awareness, mass media, special education, Saudi society.

\section{Recommended Citation}

Abusukkar, O. M. (2020). Level of awareness of autism spectrum disorder among members of Saudi Society: An exploratory study. Ankara University Faculty of Educational Sciences Journal of Special Education, 21(2), 227-246. doi: 10.21565/ozelegitimdergisi.513953

${ }^{*}$ Corresponding Author: Assist. Prof., E-mail: dr.ola.sukkar@gmail.com, https://orcid.org/0000-0001-7923-1378 
Autism spectrum disorder (ASD) is a pervasive neurodevelopmental disorder generally first diagnosed in childhood around 2-3 years old and it is characterized by impairments in social interaction and communication; problems relating to people, things, and events; and restricted, repetitive patterns of behavior, interests or activities (American Psychiatric Association [APA], 2013; Hallahan, Kauffiman, \& Pullen, 2009; Omer, 2011). Children with ASD demonstrate persistent deficits in language development and sensory perception with negative impact on social interaction, so they ignore others, prefer being alone, show inappropriate facial expressions, experience repetitive motor actions, and exhibit rage as a response to any attempt to pull them out of their closed world or any outside pressure (Sayed-Ahmed, 2012; Yoo, 2016). ASD is considered one of the most mysterious neurodevelopmental disorders, due to the difficulty of identifying its real causes, the severity of its non-adaptive behavior patterns, and the resulted neurological deficit that affects brain function and the various aspects of development (APA, 2013; Imam \& Jwaleed, 2010).

Neni, Latif, Wong, and Lua (2010) agree that ASD is a common neurodevelopmental disorder among children who exhibit challenging behaviors not only during childhood but also during adolescence and adulthood and it represents a great challenge for families of these individuals since it requires special care methods. The last five decades have witnessed a highly increased rate of ASD prevalence as the World Health Organization [WHO] reported that 1 out of 160 children around the world are diagnosed with ASD in 2017 (as cited by Doha International Family Institute, 2018). According to the estimates, in 2018 the rate of ASD prevalence has reached 1 out of 59 children in the United States of America (USA), indicating a 15 percent increase in prevalence rate in two years (Autism Speaks, 2018). In the United Kingdom, 10\% of children aged 0 to 3 years old are diagnosed with ASD, which means $0.1 \%$ of all children in this age group (Buescher, Cidav, Knapp, \& Mandell, 2014). For the countries of the Arab World, we find that very limited research has been conducted on the diagnosis of children with ASD. As asserted by Hassan (2019), while much progress is being made, ASD research in the Arab world remains very limited. The prevalence of ASD in Lebanon is 1 out of 66 children (Chaaya, Saab, Maalouf, \& Boustany, 2016). According to the autism diagnostic test applied at Dubai Autism Centre, autism affects 1 in 146 births (0.68\%) in Dubai (Al-abbady, Hessian, \& Alaam, 2017) and in Sultanate of Oman, it reached 1.4 out of 10.000 children, i.e. 1:4 for males and females (Al-Ansari \& Ahmed, 2013). For ASD prevalence in Saudi Arabia, governmental statistics report that the rate of children with autism has been recently increased by $15 \%$ to $17 \%$ (Facilitating Services for Autistics, 2017). According to these statistics, the rate of ASD prevalence has increased significantly representing a threatening indicator and a social burden for families. It thus necessitates conducting more identification procedures, early detection, and early interventions that can be effective in helping the treatment of children with autism. However, public awareness of the disorder is still limited among the majority of society members, more specifically in less affluent and non-Western nations where services and programs for children with ASD are less available (Hassan, 2019; Johnson, Porter, \& McPherson, 2012). Recently, efforts have been intensified to raise public awareness of the disorder and its symptoms (Chatkewitz \& Losonczy-Marshall, 2014). Public awareness of ASD symptoms plays a very important role in its early identification in children. While a lack of awareness, among parents and health professionals, in particular, represents a critical problem (Heys et al., 2017). According to Basha (2014), Dolah, Yahaya and Chong (2011), Heys et al. (2017), and Shamsudin and Abdul Rahman (2014), individuals who have a low level of knowledge about ASD often perceive these children negatively. Previous studies show that health caregivers, including physicians, dentists, pharmacists, physical therapists, nurses, and students of medical colleges who do not provide services for children with ASD have a low level of awareness of this disorder (Alotaibi \& Almalki, 2016; Heys et al., 2017; Imran et al., 2011; Muhammad, Al-Deen, \& Abdul-Muhsin, 2013; Rahbar, Ibrahim, \& Assassi, 2011). Lack of ASD awareness leads to the circulation of inaccurate information and misconception resulting in the formation of a negative attitude towards people with ASD (Ryan, 2013). According to Dolah et al. (2011), considerable effort has done to aid in diagnoses and treatment of the disorder, resulting in remarkable tools and methods that have the potential of improving the everyday life of a person with autism. However, the majority of respondents do not have even basic knowledge about autism; they do not understand autism and its symptoms. Raising awareness about autism and disseminating correct information about it, can help reduce its severity. Media is one of the largest sources of information about 
autism among society members; however, it is full of accurate as well as inaccurate information, resulting in inaccurate beliefs and misconceptions. Accordingly, only specialists and health professionals should be responsible for providing individuals with accurate information about the disorder (Ryan, 2013).

Previous studies have shown interest in identifying the level of ASD awareness among members of various societies. Imran et al. (2011) aimed at evaluating the baseline knowledge and misconceptions regarding autism among healthcare professionals in Pakistan. Results concluded professionals are more familiar with the utilization of the Diagnostic and Statistical Manual of Mental Disorders- 4th Version-Text Revision (DSM-IV-TR) criteria when diagnosing Autistic Disorder. Non-physicians were comparatively more likely to correctly identify diagnostic features of autism. However, significant misunderstandings of some of the salient features of autism were present in both groups. Rahbar et al. (2011) aimed at assessing the knowledge and attitude of general practitioners in Karachi regarding autism. Results showed that general practitioners who obtained their Medical Degree in the last five years are more likely to report knowledge about autism. However, many participants held misconceptions regarding the signs and symptoms of the disorder. Muhammad et al. (2013) aimed at assessing the level of autism knowledge among health care providers in Baghdad. Results indicated more than half $(56.5 \%)$ of the respondents have a high level of autism knowledge. There was a highly significant statistical difference between the specialty of participants with the highest mean score recorded among the pediatric specialists and the lowest mean score among the general practitioners. Thus, it can be excluded that the level of ASD awareness among healthcare professionals varies according to specialization and years of work.

Johnson et al. (2012) aimed at examining autism knowledge among pre-service teachers specialized in children birth through age five in the USA. The study concluded that $75 \%$ of the participants had limited experience in interacting with children with autism. Lack of autism knowledge among participants is influenced by age, perceived autism knowledge, experience in working with children with autism and the number of sources where participants received autism information. Haimour and Obaidat (2013) aimed at finding out what teachers knew about autism in Jeddah, Saudi Arabia. Results indicated that schoolteachers had an acceptable approaching to a weak level of knowledge about autism. There were significant differences in the teachers' knowledge about autism depending on teachers' position, educational level, teaching experience, and contact with students with autism favoring special education teachers, more advanced level of education and teaching experience, and those with the previous contact with students with autism. Arif, Niazy, Hassan, and Ahmed (2013) aimed at assessing the knowledge and perception of teachers regarding autism in private and public schools of Karachi, Pakistan. Results concluded that $55 \%$ of the teachers knew about autism through the media and only $9 \%$ had formal training through workshops on autism. The majority of the teachers (57\%) said that proper training is required for teaching children with autism. Shetty and Rai (2014) assessed the level of autism knowledge among teachers in a primary school in India and identified variables affecting this knowledge. Results showed that while most teachers had low knowledge levels of the disorder, $21 \%$ of them had good knowledge because they had attended training programs about autism. Al-Sharbati et al. (2015) aimed at evaluating teachers' awareness about ASD in Oman. Though 89\% of respondents had heard about ASD, misconceptions were found to be common among them. Such lack of awareness was attributed to sociocultural patterning and mass media. Accordingly, teachers showed various levels of ASD awareness affected by various variables including gender, academic qualification, years of experience, and source of information about ASD.Dillenburger, Jordan, McKerr, Devine, and Keenan (2013) aimed at identifying the level of autism awareness among children and youth in Northern Ireland. Results concluded that autism awareness was higher for teenagers (80\%) than for younger children $(50 \%)$. Many of the children knew someone with autism (50\%) and generally reported positive and supportive attitudes. In addition, a higher number of children and young people self-reported being on the autism spectrum. Shamsudin and Abdul Rahman (2014) aimed to identify the level of ASD awareness among society members in Malaysia. Results concluded that, while most participants were familiar with the term autism but still many of them did not understand the characteristics of children with autism. Their source of information about the disorder was media, newspapers, or friends. Basha (2014) aimed at detecting Palestinians knowledge and understanding of autism. Results indicated that most respondents had misconceptions and a low level of information about the disorder; $35 \%$ reported that it is a 
behavioral disorder, $19 \%$ said it is a mental disorder, and $81 \%$ drew their information from the media. Jensen et al. (2015) surveyed a sample of general adults, within the Northern Region of Denmark, about their knowledge, attitudes, and beliefs about individuals with autism and schizophrenia. Respondents possessed basic knowledge and were able to differentiate between the two disorders. They were more positive towards interacting with individuals with autism, but the desire for social distancing was pronounced for both disorders in more intimate relationships. Heys et al. (2017) examined parents' and professionals' understanding of autism in one low-income country, Nepal. Results indicated that parents of typically developing children and professionals had little explicit awareness of autism. Other participants including parents of ordinary children, pediatricians, general practitioners, primary teachers, pre-school teachers, and public health providers had a low level of ASD awareness. Tipton and Blacher (2014) reported on a college community's views of the diagnostic characteristics and causes associated with ASD. A total of $76 \%$ of respondents had correct answers and reported that they or someone in their family had autism. Demographic variables of respondent gender, age, education, and role at the university independently accounted for significant, though modest, variance in autism knowledge. Obeid, Daou, DeNigris, and Simpson (2015) aimed at comparing knowledge and stigma associated with ASD in a country with limited autism resources, Lebanon, and the USA. Although students in the USA exhibited higher overall knowledge and lower stigma towards ASD, certain misconceptions were more apparent in the USA than in Lebanon. Participation in the training was associated with decreased stigma and increased knowledge in both countries. Dillenburger, Jordan, McKerr, Lloyd, and Schubotz (2017) identified the level of autism awareness among children and youth. Results indicated that autism awareness was higher for teenagers (80\%) than for the younger children (50\%). Many of the children knew someone with autism (50\%) and generally reported positive and supportive attitudes. The self-reported prevalence of autism was $3.1 \%$ for teenagers and $2.7 \%$ for younger children.

It can be extracted that, the existing literature has focused on identifying individuals' degree of ASD knowledge including healthcare providers, teachers, and young people, according to some variables (gender, age, academic degree, and profession, etc.) in different societies and environments. Most studies revealed a low level of ASD awareness in different societies such as Northern Ireland, Malaysia, Nepal, Lebanon, and Palestine. Further, analysis of the literature reveals that this low level of ASD awareness is prevalent not only among common people but also among teachers and healthcare providers. To the author's knowledge, no previous study has identified the level of ASD awareness in Saudi society, except for Haimour and Obaidat (2013). However, in that study it was limited to Saudi teachers in the region of Jeddah and did not deal with any other Saudi classes. Thus, the current study tends to fill this knowledge gap by identifying the level of ASD awareness among members of the Saudi society according to the administrative district, gender, age, academic qualification, and profession. It attempts to answers the following main question: What is the level of ASD awareness among members of Saudi society? It can be further divided into the following sub-questions: (1) What is the percentage of Saudi individuals who have information about ASD? (2) What is the source of information of Saudi individuals about ASD? Are there statistically significant differences between the mean scores of (3) individuals from different districts; (4) male and female individuals; (5) young and old individuals; (6) individuals with different academic qualifications; (7) individuals with different professions on ASD awareness scale? Therefore, the current study is of significance to the field of special education. It fills a literature gap by identifying the level of ASD awareness among members of Saudi society since the previous studies conducted in the same context are very rare. In light of the study results of the level of ASD awareness among Saudis according to age, gender, profession, academic qualification, and administrative district, awareness programs can be developed. These programs shall provide society members with various information relevant to autism causes, symptoms, diagnoses, and treatments. Thus, the current study contributes to raising social awareness about autism, which inevitably helps early detection and intervention for many cases in Saudi Arabia. Raising social awareness about autism helps in the early detection of the disorder and accordingly in the early intervention and provision of proper treatment and required support (Yoo, 2016). 


\section{Method}

For achieving the study objectives, the author adopts the descriptive-analytical approach. This approach helps study the real aspects of a phenomenon by providing a precise quantitative as well as qualitative description of it. The qualitative description helps describe the phenomenon as it is in the real context, while the quantitative description provides numerical indications that help identify the real quantity or size of the phenomenon in question (Abbas, Baker, Mustafa, \& Muhammed, 2007).

\section{Data Collection}

The study data were collected from Princess Nourah bint Abdulrahman University, a national university in Saudi Arabia. The study population includes university students, employees, and their relatives and acquaintances. They were asked to participate in the study by sending messages on WhatsApp groups, via e-mail, and posting on Twitter. The author utilized Survey-Monkey software (http://survey-monkey.com/) to prepare the ASD Awareness Scale. The scale was distributed to the study population through sending messages to WhatsApp groups of the students of the special education department, College of Education, Princess Nourah bint Abdulrahman University. The scale was sent also to all the employees of Princess Nourah bint Abdulrahman University via the e-mail. The author also has published the scale on her personal account on Twitter. She asked the participants to respond to the scale and to ask their families and acquaintances to participate.

\section{Sampling}

Two months later after distributing the scale, the responses were gathered and reached 1.000 responses. A total of 112 incomplete responses were excluded. The study sample thus consisted of 888 participants, where 174 were males and 714 were females, aged 18-58 years old with an age mean of 35.33 and a standard deviation of 9.858. Table 1 shows the sample distribution according to the study variables.

Table 1

Sample Distribution According to Variables

\begin{tabular}{|c|c|c|c|c|c|c|c|}
\hline \multicolumn{8}{|c|}{ Variables } \\
\hline \multirow[t]{2}{*}{ Gender } & & \multicolumn{2}{|c|}{ Profession } & \multicolumn{2}{|c|}{ Academic qualification } & \multicolumn{2}{|c|}{ Administrative district } \\
\hline & $N$ & Field & $N$ & Degree & $N$ & Region & $N$ \\
\hline \multirow{5}{*}{ Male } & \multirow{5}{*}{174} & Special education & 44 & Ph.D. & 27 & Eastern & 27 \\
\hline & & Public education & 47 & Master & 30 & Western & 46 \\
\hline & & Medicine & 11 & Bachelor & 56 & Central & 59 \\
\hline & & Other professions & 52 & Secondary & 49 & Northern & 17 \\
\hline & & Unemployed & 20 & Moderate or less & 12 & Southern & 25 \\
\hline \multirow{5}{*}{ Female } & \multirow{5}{*}{714} & Special education & 37 & Ph.D. & 28 & Eastern & 80 \\
\hline & & Public education & 261 & Master & 71 & Western & 124 \\
\hline & & Medicine & 36 & Bachelor & 540 & Central & 394 \\
\hline & & Other professions & 173 & Secondary & 60 & Northern & 50 \\
\hline & & Unemployed & 207 & Moderate or less & 15 & Southern & 66 \\
\hline Total & 888 & & 888 & & 888 & & 888 \\
\hline
\end{tabular}

Based on Table 1, the participants were subdivided into groups according to the study variables. For the profession variable, the sample was divided into five groups as follows: 81 participants specialized in special education, including special education faculty, special education teacher, special education co-teacher, psychologist, social worker, speech disorder specialist, special education program supervisor, and special education student. The second group consisted of 308 public education specialists, including faculty, teachers, student advisor, secretary, and students. The third group compromised 47 participants specialized in medicine, including 
doctors, dentists, pharmacists, physiotherapists, nurses, and medical college students. The fourth group consisted of 225 participants of other professions, including governmental employee, engineer, pilot, director, lawyer, soldiers, freelancers, and salesperson. The fifth group consisted of 227 unemployed participants, including housewives and unemployed graduates. According to academic qualification, the sample compromised $55 \mathrm{Ph} . \mathrm{D}$. holders specialized in special education, psychology, curricula, and instruction methods, medicine, pediatrics, dentistry, and pharmacology; 101 master's degree holders; 596 bachelor's degree holders; 109 secondary school graduates; and 27 individuals with moderate or less education. With reference to the administrative district, participants are found to belong to five regions distributed as 107 from the Eastern Region, 170 from the Western Region, 453 from the Central Region, 67 from the Northern Region and 91 from the Southern Region.

\section{Instrument}

ASD Awareness Scale. In order to identify the ASD awareness levels among Saudi society members, the ASD Awareness Scale was prepared by the author. After reviewing the literature relevant to the problem of ASD awareness and various scales, the objectives of the scale were identified. In the light of the results concluded from reviewing the literature, an initial form of the scale was prepared and submitted to a panel of three examiners specialized in Special Education to verify its appropriateness. According to their suggestions, some modifications were made, and the final form of the scale was set. The scale consisted of two parts. The first part collects general information about the participants, such as name, age, gender, profession, administrative district, in addition to a question about how much information about autism does the participant have and another question about the source of this information. The second part consisted of 32 items distributed to four domains, i.e., 8 items for each domain. It measures the level of Saudis' awareness of the behavioral problems associated with ASD. The domains are communication, social interaction, repetitive behavior, and ASD-based problems.

Adopting a three-pointed Likert scale, response to the scale items ranged to three levels: "I do not know (0)", "I likely know (1)," and "I know (2)". The scale total score ranged from 0 to 64, as a high score indicates a high level of ASD awareness, and a low score indicates a low level of awareness.

Scale validity and reliability. To verify the psychometric characteristics of the construct, it was applied to a pilot sample consisting of 100 participants, 22 males and 78 females, aged between 19-56 years old.

Face validity. The final form of the ASD Awareness Scale was presented to five experts who are faculty members in the Special Education Department. They all agreed on the validity of the presented construct to measure the level of ASD awareness among the members of Saudi society.

Content validity. To verify the validity of the construct items, correlation coefficients between the score of each item and the total score of its domain after omitting the item score were calculated. Cronbach's alpha correlations were calculated as each correlation indicates the scale reliability and criterion validity of its items (Abu Hashem, 2004), as shown in Table 2.

Table 2

Correlation Coefficient for Each Item of The Domains of ASD Awareness Scale $(N=100)$.

\begin{tabular}{lccccc}
\hline Domain & Item & Correlation coefficient & Domain & Item & Correlation coefficient \\
\hline & 1 & .66 & .78 & 17 & .75 \\
& 2 & .75 & Repetitive behaviors & 18 & .45 \\
Communication & 3 & .71 & & 19 & .71 \\
& 4 & .79 & 21 & .61 & .71 \\
& 5 & .55 & 22 & .59 \\
& 6 & .65 & 23 & .62 \\
\hline
\end{tabular}


Table 2 (continue)

\begin{tabular}{lccccc}
\hline Domain & Item & Correlation coefficient & Domain & Item & Correlation coefficient \\
\hline \multirow{5}{*}{ Social interaction } & 9 & .74 & 25 & .75 \\
& 10 & .74 & 26 & .58 \\
& 11 & .74 & ASD-based problems & 28 & .64 \\
& 12 & .74 & & 29 & .57 \\
& 13 & .72 & 30 & .74 \\
& 14 & .75 & 31 & .67 \\
& 15 & .74 & 32 & .49 \\
\hline
\end{tabular}

Table 2 indicates that all the correlation coefficients between the item score and the total score of its domain after omitting the domain score are statistically significant at $p=.01$, which confirms that the scale items have an acceptable degree of validity.

Criterion validity. To verify the validity of the construct domains, correlation coefficients between the score of each domain and the total score of the scale after omitting the domain score were calculated, as shown in Table 3.

Table 3

Correlation Coefficient of ASD Awareness Scale Domains $(N=100)$

\begin{tabular}{lc}
\hline Domain & Correlation coefficient \\
\hline Communication & .95 \\
Social interaction & .94 \\
Repetitive behaviors & .88 \\
ASD-based problems & .82 \\
\hline
\end{tabular}

Table 3 shows that correlation coefficients between the item score and the total score of its domain after omitting the domain score are statistically significant at $p=.01$, which confirms that the scale domains have an acceptable degree of validity.

Scale reliability. Scale domains reliability calculated by Cronbach's alpha, i.e. Alpha equation for internal consistency as follows:

$\alpha=\frac{n}{n-1}\left(1-\frac{\sum_{i=1}^{n} \sigma_{Y_{i}}^{2}}{\sigma_{X}^{2}}\right)$ where $n$ is the number of items, $\sigma_{Y_{i}}^{2}$ is the variance of the total scores, and $\sigma_{X}^{2}$ is the variance of the scale.

Results are .89 for communication, .85 for social interaction, .81 repetitive behaviors, .84 for ASD-based problems, and .96 for the scale total score. It means the reliability values of the scale domains are high.

\section{Results and Discussion}

Analysis of the study results shows that participants have no information about autism and a low level of ASD awareness. For the source of getting information about ASD, media plays the largest and most important role in raising ASD awareness among individuals. Results indicate that there are no statistically significant differences in the level of ASD awareness in the mean scores of participants from different administrative districts. There is a statistically significant difference in the mean scores of male and female participants in the level of ASD awareness, in favor of females. There is a statistically significant difference in the mean scores of the young and old participants in the level of ASD awareness, in favor of the young. The highest level of ASD awareness was among holders of 
Ph.D. and the lowest was among holders of moderate and lower qualifications. In terms of profession, the highest ASD awareness level was among practitioners of Special Education and the lowest was among the unemployed.

Frequencies and percentages of the sample responses calculated to determine whether they have information about the disorder or not, as shown in Table 4.

Table 4

Percentages of The Sample Responses According to Their Information About ASD $(N=888)$.

\begin{tabular}{lcccc}
\hline & Having information about ASD & Not having information about ASD \\
\hline Source of information & Number & Percentage & Number & Percentage \\
\hline Work or specialization in Special Education & 77 & $19.3 \%$ & & $55.2 \%$ \\
Dealing with a person with autism & 95 & $23.9 \%$ & 490 & $55.2 \%$ \\
Mass media & 226 & $56.8 \%$ & & 490 \\
\hline Total & 398 & $44.8 \%$ & & 50 \\
\hline
\end{tabular}

Table 4 showed that most of the sample respondents do not have information about ASD. In addition, it referred to the important role played by mass media as a basic source of information on the disorder. It can be explained that ASD is a neurodevelopmental disorder that has been discovered later than other disorders. In Saudi Arabia, attention to this disorder began over the past fifteen years, as the Special Education Department of the Education Colleges started to specify courses for teaching autism. In addition, the Ministry of Education began to establish programs pertaining to the disorder (Alzahrani \& Brigham, 2017). Accordingly, most individuals not specialized in Special Education, as well as those who did not deal with a child with autism child, have no information about the disorder.

With the increasing attention given to autism by Saudi authority, numerous scientific conferences and seminars held for discussing the disorder, its relevant problems and negative effects on the child with autism, as well as a health care provider. Mass media, in general, and visual media, in particular, address the disorder through interviews with specialists through satellite channels and social media discussions. In other words, mass media, especially TV channels, contributed to raising people's awareness about autism. It represents a source of information about the disorder for $56.8 \%$ of the participants from different districts with various economic and social levels. These results are consistent with (Al-Sharbati et al., 2015; Arif et al., 2013; Basha, 2014; Heys et al., 2017; Johnson et al., 2012; Shamsudin \& Abdul Rahman, 2014; Shetty \& Rai, 2014) that most members of the society who do not work in the field of Special Education or psychiatry have a low level of ASD awareness and their source of information about the disorder is mass media.

ANOVA Test applied to calculate the significance of differences between the mean scores of individuals according to districts on ASD awareness scale, as shown in Table 5.

Table 5

ANOVA Results for The Mean Scores of Individuals According to Districts on ASD Awareness Scale $(N=888)$

\begin{tabular}{lccccc}
\hline Source of variance & Sum of squares & df & Mean squares & F-ratio & $p$ \\
\hline Among groups & 261.60 & 4 & 65.40 & \multirow{2}{*}{1.99} & .01 \\
Within groups & 28909.77 & 883 & 32.74 & & \\
\hline Total & 29171 & 887 & & & \\
\hline
\end{tabular}

Table 5 indicates that there are no statistically significant differences in the level of ASD awareness among participants due to the different districts where they live. It can be explained that Saudi Arabia is concerned with individuals with ASD throughout the whole Kingdom without any distinction between regions. It is emphasized by the establishment of Special Education Departments in all Colleges of Education in the Kingdom. In addition to encouraging those responsible for this field in all regions of the Kingdom to set up conferences and scientific seminars to discuss the various problems related to the disorder. Workshops and training courses delivered to 
developing Saudi people's awareness of autism. Mass media, especially TV channels, provide Saudi people in different regions with information about the disorder (Al-Khashramy, 2003).

T-test applied to calculate differences between the mean scores of male and female individuals on ASD awareness scale independent groups, as shown in Table 6.

Table 6

T-test Results and Significant Differences in The Level of ASD Awareness Among Male and Female Participants Mean Scores $(N=888)$

\begin{tabular}{lccccc}
\hline Groups & Number & Mean & Sd & $t$ & $p$ \\
\hline Male & 174 & 40.37 & 5.20 & \multirow{2}{*}{14.88} & .01 \\
Female & 714 & 46.83 & 5.11 & & \\
\hline
\end{tabular}

Table 6 indicated statistically significant difference among male and female members of society in the level of ASD awareness, in favor of females. Female participants show a higher level of awareness about the disorder than male participants do. It can be referred to the inherited passion of motherhood among female participants, which makes them closer and more compassionate for children with autism (Tipton \& Blacher, 2014). Mothers and sisters of children with autism are their caregivers, so they look for any of information about the disorder, so they can help their relatives with autism. In addition, most attendees of ASD workshops and training are females, which in turn makes their level of knowledge about ASD higher than that of males. The result is consistent with (Dillenburger et al., 2013; Tipton \& Blacher, 2014) confirming that the females have a higher level of ASD awareness than males. However, it is inconsistent with (Haimour \& Obaidat, 2013) which concluded that there are no significant differences in the level of ASD awareness attributed to gender variable.

Participants were divided into two groups: youth between 18-38 years old and old between 39-58 years old and T-test applied to calculate differences between the independent groups, as shown in Table 7.

Table 7

T-test Results and Significant Differences in The Level of ASD Awareness Among Young and Old Participants Mean Scores $(N=888)$

\begin{tabular}{lccccc}
\hline Groups & Number & Mean & Sd & $t$ & $p$ \\
\hline Young & 528 & 46.08 & 5.58 & \multirow{2}{*}{3.22} & \multirow{2}{*}{01} \\
Old & 360 & 44.82 & 5.87 & & \\
\hline
\end{tabular}

Table 7 indicated statistically significant differences between the mean scores of young and old participants in the level of ASD awareness, favoring young participants $(p=.01)$.

It can be interpreted that remarkable attention to autism in the Arab world in general, and in Saudi Arabia, in particular, began over the last twenty years. It means that younger individuals have attended conferences and seminars relevant to the disorder during the period of their studies at the university, resulting in high level of information about autism among them. In addition, younger participants have the capabilities and skills of using social media more than the older. Accordingly, they can search for and circulate ASD-related information faster than older participants can. It was emphasized by Nekolas Rurist, a digitization and education consultant in the German National Association of Senior Citizens' Organizations, stating that old people are worried and have concerns about using social media. They doubt their ability to use and manage social media, while many others see them as unimportant. Accordingly, seniors are unable to indulge in social media platforms (Dostor, 2019).

This result is consistent with results of previous researchers (Haimour \& Obaidat, 2013; Johnson et al., 2012; Rahbar et al., 2011; Tipton \& Blacher, 2014) demonstrating that the level of ASD awareness and knowledge was higher among younger participants than the older. However, it is inconsistent with (Dillenburger et al., 2013; Obeid et al., 2015; Tipton \& Blacher, 2014) concluding that the level of ASD awareness was higher among old participants than younger ones. 
ANOVA Test applied to calculate differences between the mean scores of individuals according to academic qualification on ASD awareness scale, as shown in Table 8.

Table 8

ANOVA Results for The Mean Scores of Individuals According to Their Academic Qualification on ASD Awareness Scale $(N=888)$

\begin{tabular}{lccccc}
\hline Source of variance & Sum of squares & $d f$ & Mean squares & F-ratio & $p$ \\
\hline Among groups & 4547.11 & 4 & 1136.77 & \multirow{2}{*}{40.764} & .01 \\
Within groups & 24624.27 & 883 & 27.88 & & \\
\hline Total & 29171.38 & 887 & & & \\
\hline
\end{tabular}

Table 8 indicated statistically significant differences at $p=.01$ among participants mean scores due to academic qualification on ASD awareness scale. To determine the direction of significant differences, Scheffe's Test applied to participants' mean scores, according to the academic qualification variable, as shown in Table 9.

Table 9

F Value for Mean Scores Differences on ASD Awareness Scale, According to Academic Qualification Variable $(N=888)$

\begin{tabular}{lcccccc}
\hline Groups & Number & Mean & Ph.D. & Masters & BSC & Moderate or lower \\
\hline Ph.D. & 55 & 51.07 & & & & \\
Masters & 101 & 47.49 & $* * 3.57$ & & & \\
Bachelor & 596 & 45.64 & $* * 5.43$ & $* * 1.85$ & & \\
Secondary education & 109 & 42.44 & $* * 8.62$ & $* * 5.04$ & $* * 3.19$ & $* * 4.19$ \\
Moderate or less & 27 & 38.25 & $* * 1281$ & $* * 9.23$ & $* * 7.38$ & $* 38$ \\
\hline
\end{tabular}

**Significant at $p=.01$

Results of Scheffe's test in Table 9 show that there are statistically significant differences at the level of $p$ $=.01$ between the mean scores of participants with Ph.D., and participants of other groups in the level of ASD awareness, favoring Ph.D. holders. There are statistically significant differences at the level of $p=.01$ between the mean scores of participants with a master's degree, and participants of other groups in the level of ASD awareness, favoring master's degree holders. There are statistically significant differences at the level of $p=.01$ between the mean scores of participants with a bachelor's degree, and participants of other groups in the level of ASD awareness, favoring bachelor's degree holders. There are statistically significant differences at the level of $p=.01$ between the mean scores of participants with a secondary degree, and participants of other groups in the level of ASD awareness, favoring secondary degree holders.

It can be drawn that the highest level of ASD awareness is among participants with a Ph.D. degree, and the lowest level is among participants with a moderate degree and lower. These results can be explained that participants with high academic qualifications have spent more time at educational institutions than participants with lower qualifications. In addition, they have taught more educational courses resulting in a higher level of general knowledge and culture, including ASD knowledge. They attend or participate in seminars, conferences, and workshops organized by the universities on the disorder. All of these elements contribute to raising the level of ASD awareness among participants with higher academic qualifications. These results are consistent with (Dillenburger et al., 2013; Haimour \& Obaidat, 2013; Tipton \& Blacher, 2014) showing that the level of ASD awareness increases among participants with higher educational levels.

ANOVA Test applied to calculate the significance of differences between the mean scores of participants according to the variable of the profession on ASD awareness scale, as shown in Table 10.

Table 10 shows statistically significant differences at the level of $p=.01$ between the mean scores of participants with different professions in the level of ASD awareness. To determine the direction of significant 
differences between the mean scores according to participants' profession, Scheffe's test was applied, as shown in Table 11.

Table 10

ANOVA Results for The Mean Scores of Participants According to Profession on ASD Awareness Scale $(N=888)$

\begin{tabular}{lccccc}
\hline Source of variance & Sum of squares & $d f$ & Mean squares & F-ratio & $p$ \\
\hline Among groups & 6361.52 & 4 & 1590.38 & \multirow{2}{*}{61.56} & \multirow{2}{*}{01} \\
Within groups & 22809.86 & 883 & 25.83 & & \\
\hline Total & 29171.38 & 887 & & & \\
\hline
\end{tabular}

Table 11

F Value for Mean Scores Differences on ASD Awareness Scale, According to Profession Variable $(N=888)$

\begin{tabular}{lcccccc}
\hline Group & No & Mean & Special Education & Public education & Medicine & Other professions \\
\hline Special Education & 81 & 51.98 & & & & \\
Public education & 308 & 46.22 & $* * 5.76$ & & & \\
Medicine & 47 & 49.06 & $* * 2.92$ & $* *-2.84$ & & \\
Other professions & 227 & 44.76 & $* * 7.22$ & $* * 1.45$ & $* * 4.30$ & $* * 6.60$ \\
Unemployed & 225 & 42.46 & $* * 9.52$ & $* * 3.75$ & $* 2.29$ \\
\hline
\end{tabular}

**Significant at $p=.01$

Table 11 shows that there are statistically significant differences at $p=.01$ between participants working in Special Education and participants working in other fields and unemployed, favoring those working in the field of Special Education. There are statistically significant differences at $p=.01$ between participants working in the field of Public Education and participants working in other fields. The significant differences are reversed, i.e., participants working in medicine have a higher level of ASD awareness than participants working in the field of Public Education have. There are statistically significant differences between participants working in Public Education and participants practicing other professions and unemployed, favoring participants working in Public Education. There are statistically significant differences at $p=.01$ between participants working in Medicine and participants working in other fields and unemployed, favoring those working in the field of Medicine. There are statistically significant differences at $p=.01$ between participants practicing other professions and unemployed participants, favoring those practicing other professions.

It can be concluded that participants working in Special Education have a higher level of ASD awareness than those practicing other professions and unemployed. These results can be explained that individuals working in the field of Special Education, such as teachers, social specialists, psychologists, and speech specialists, have studied subjects related to autism in the university. It helped them construct knowledge about the disorder. In addition, dealing with children with autism contributes to increasing their level of ASD awareness. Their knowledge consists of not only theoretical study but also practical interaction with people with autism. Therefore, their level of ASD awareness is higher and more accurate than that of other groups. Because of the increasing numbers of children with ASD, physicians, pediatricians and psychiatrists are more interested in autism. There is a growing increase in the number of children with autism visiting pediatric clinics, psychiatric clinics, and speech clinics in public and private hospitals. Accordingly, more scientific and medical studies are conducted on the disorder. Nursing staff, as well as health caregivers, have a high level of information about ASD, but lower than that of individuals working in the field of Special Education. In the field of public education, the Ministry of Education has applied academic integration system for students with ASD in many public schools. Individuals working in these schools can closely deal with students with autism and gain more information about the disorder. Accordingly, they show a higher level of ASD awareness than those practicing other professions and unemployed. For individuals working in other professions, they socially interact with some of those who work in the field of Special Education or Public Education schools that include ASD programs or with those working in the field of medicine and health service providers to individuals with ASD. It helps them acquire some information about the disorder, so they show a higher level of ASD awareness than the unemployed do. These results are consistent with the results of Haimour and Obaidat, 2013; Heys et al., 2017 concluding that teachers and Special Education specialists have 
a higher level of ASD awareness than that of Public Education teachers. In addition, teachers who have a previous connection to a person with autism have a higher level of ASD awareness than that of teachers who do not have this connection (Haimour \& Obaidat, 2013). Individuals working in medical specialties related to ASD have a higher level of ASD awareness than individuals who practice other professions (Imran et al., 2011; Muhammad et al., 2013). Individuals who have a connection to a family member, friend, or colleague with autism than those who do not know someone with the disorder (Dillenburger et al., 2013).

\section{Conclusion}

Autism is a neurodevelopmental disorder characterized by impairments in social interaction, verbal and nonverbal communication, and repetitive behavioral patterns. The fact that autism occurs in a broad spectrum means that every person is affected differently and demonstrates different capabilities depending on the location within that spectrum. The current study aimed at identifying the level of autism awareness among Saudi society members according to the variables of gender, age, academic qualification, and profession. It concluded that while $44.8 \%$ of the participants have information about ASD, 55.2\% of them have no information about the disorder. Mass media represents the source of information for $56.8 \%$ of the participants. There were statistically significant differences in the level of ASD awareness between male and female participants, in favor of female participants, and between young and old participants, in favor of young participants. The highest ASD awareness level was among Ph.D. holders, and the lowest was among holders of moderate and lower qualifications. In terms of profession, the highest ASD awareness level was among practitioners of Special Education and the lowest was among the unemployed. Although there is no accurate explanation for the causes of the disorder, the early proper intervention has proven effective in improving skills and communication abilities among individuals with ASD. It cannot be denied that raising social awareness about the disorder contributes to its early detection and to the provision of proper intervention. It also helps offer the required services and support to the families of children with ASD. Thus, raising social awareness about ASD is of advantage to the child with autism, family, teachers, healthcare providers, and ultimately the whole society.

\section{Limitations}

The current study has inevitably certain limitations. For its objective, it is limited to identifying the level of awareness of ASD in relevance to the domains of communication, social interaction, repetitive behaviors, and ASDbased problems. The spatial limitations of the study include five districts of Saudi Arabia. For the temporal limitation, the study was conducted in the second semester of 2017/2018 academic year.

\section{Suggestions and Recommendations}

In light of the study results, raising awareness among members of the Saudi society about the early stages symptoms of ASD is a must. It can be accomplished through mass media, holding training courses and seminars, and affording bulletins and specialized books for parents. The role of the school and the family should be activated in order to raise social awareness of the disorder as well as to develop social skills among children with ASD. At the level of the government, the Ministry of Education in collaboration with the institutions of special education has to hold training courses for teachers about autism spectrum disorder and ways of detection. In addition, a specialized team should be trained to diagnosis and evaluate autism among students. In this respect, preparing a guide for teachers and educators that help identify the symptoms of ASD and the importance of early intervention is highly recommended. The fact is that there is a dire need to develop a comprehensive policy aimed at improving the support for students with ASD and correcting the relevant misconceptions and definitions prevalent in Saudi society. Therefore, raising social awareness about autism requires national cooperation among the various sectors of health, education, and community.

While much progress is being made to ASD related-research in the Arab world, it remains very limited and there is a need for more to be conducted. For further research, the author recommends conducting a similar study that investigates the level of awareness of other neurodevelopmental disorders. In addition, identifying the challenges that face individuals with ASD in Saudi society shall be of great importance for allocating the proper funding and support. Establishing a database of the rates of ASD prevalence in Saudi Arabia is important for research centers and educational and healthcare institutions. It helps identify the financial burden of ASD and the needed financial support and health services. In the same vein, it requires preparing programs and special units for educating Saudi families and raising their awareness about ASD, its symptoms, and the importance of early intervention. 


\section{References}

Abbas, K., Baker, N., Mustafa, M., \& Muhammed, F. (2007). An introduction to the methods of education and psychology research. Amman: Jordan: Dar El-Mysarah for Publication and Distribution.

Abu Hashem, A. (2004). The statistical guide for data analysis using SPSS. Riyadh: Al-Rushed Library.

Al-abbady, K., Hessian, H. Y., \& Alaam, M. W. (2017). Prevalence, trend, determinants and prediction of autism spectrum disorders among Dubai population, diagnostic approach and management contexts. Journal of Pediatrics and Neonatal Care, 7(1), 1-500278. doi: 10.15406/jpnc.2017.07.00278

Al-Ansari, A. M., \& Ahmed, M. M. (2013). Epidemiology of autistic disorder in Bahrain: Prevalence and obstetric and familial characteristics. Eastern Mediterranean Health Journal, 19(9) 769-774.

Al-Khashramy, S. (2003). The development of special education in Saudi Arabia: Autism program as a model. A work paper presented at the Saudi Cultural Week in Jordan, Amman, 1-22. Retrieved from https://www.kau.edu.sa/Files/0009090/Subjects/\%D9\%88\%D8\%B1\%D9\%82\%D8\%A9\%20\%D8\%B9\% D9\%85\%D9\%84.doc

Alotaibi, F., \& Almalki, N. (2016). Parents' perceptions of early interventions and related services for children with Autism Spectrum Disorder in Saudi Arabia. International Education Studies, 9(10), 128-140. doi: 10.5539/ies.v9n10p128

Al-Sharbati, M., Al-Farsi, Y., Ouhtit, A., Waly, M., Al-Shafaee, M., Al-Farsi, O., ... Al-Adawi, S. (2015). Awareness about autism among teachers in Oman: A cross-sectional study. Autism, 19(1), 6-13. doi: $10.1177 / 1362361313508025$

Alzahrani, A., \& Brigham, F. (2017). Evaluation of special education preparation programs in the field of autism spectrum in Saudi Arabia. International Journal of Special Education, 32(4), 746-766.

American Psychiatric Association. (2013). Diagnostic and statistical manual of mental disorders (5th ed.). Washington, DC: American Psychiatric Association Press.

Arif, M., Niazy, A. Hassan, B., \& Ahmed, F. (2013). Awareness of autism in primary school teachers. Autism Research and Treatment, 2013(1), 1-5. doi: 10.1155/2013/961595.

Autism Speaks (2018). CDC increases estimate of autism's prevalence by 15 percent, to 1 in 59 children. Retrieved from https://www.autismspeaks.org/science-news/cdc-increases-estimate-autisms-prevalence-15percent-1-59-children

Basha, S. (2014). First national public opinion survey: Palestinians knowledge and understanding of autism. Italian Journal of Special Education for Inclusion, 2(1), 87-96.

Buescher, A. V., Cidav, Z., Knapp, M., \& Mandell, D. S. (2014). Costs of autism spectrum disorders in the United Kingdom and United States. JAMA Pediatrics, 168(8), 721-728. doi:10.1001/jamapediatrics.2014.210

Chaaya, M., Saab, D., Maalouf, F. T., \& Boustany, R. M. (2016). Prevalence of autism spectrum disorder in nurseries in Lebanon: A cross sectional study. Journal of Autism and Developmental Disorders, 46(2), 514-522. doi: 10.1007/s10803-015-2590-7

Chatkewitz, M., \& Losonczy-Marshall, M. (2014). Awareness of autism and perceptions of the disorder. Psychology and Social Behavior Research, 2(2), 46-52. doi: 10.12966/psbr.06.04.2014

Dillenburger, K., Jordan, J., McKerr, L., Devine, P., \& Keenan, M. (2013). Awareness and knowledge of autism and autism interventions: A general population survey. Research in Autism Spectrum Disorders, 7(12), 1558-1567. doi: 10.1016/j.rasd.2013.09.004 
Dillenburger, K., Jordan, J., McKerr, L., Lloyd, K., \& Schubotz, D. (2017). Autism awareness in children and young people: Surveys of two populations. Journal of Intellectual Disability Research, 61(8), 766-777. doi: $10.1111 /$ jir.12389

Doha International Family Institute. (2018). The well-being of families living with autism spectrum disorder in Qatar. Retrieved from https://www.difi.org.qa/wp-content/uploads/2019/12/Autism-ENGLISH.pdf

Dolah, J., Yahaya, W., \& Chong, T. (2011). A preliminary investigation: Potential of interactive multimedia learning awareness (imla) in enhancing awareness among autism parents in Malaysia. Proceedings of the $3^{\text {rd }}$ International Conference of Teaching and Learning, Inti. International University Malaysia.

Dostor (2019). Social media unseen by seniors. El-Dostor Journal, 10(18), 9-11. Available at: https://www.dostor.org/2613200

Facilitating Services for Autistics (2017) Human Resource Development, Tawafq (1st ed.). Retrieved from https://www.hrdf.org.sa/Content/Tawafuq/Content/documents/Disability Confidence/300317_Autism_Spectrum_Disorder_Final_AR.pdf

Haimour, A., \& Obaidat, Y. (2013). School teachers' knowledge about autism in Saudi Arabia. World Journal of Education, 3(5), 45-56. doi: 10.5430/wje.v3n5p45

Hallahan, D., Kauffman, J., \& Pullen, P. (2009). Exceptional learners: An introduction to special education (11th ed). USA: Pearson Education, Inc.

Hassan, A. (2019). Arab views on autism. In Volkmar F. (Ed.) Encyclopedia of Autism Spectrum Disorders. New York, NY. Springer. doi: 10.1007/978-1-4614-6435-8_102309-1

Heys, M., Alexander, A., Medeiros, E., Kirti, M. T., Felicity, G., Rita, S., ... Elizabeth, P. (2017). Understanding parents 'and professionals' knowledge and awareness of Autism in Nepal. Autism: The International Journal of Research and Practice, 21(4), 436-449. doi: 10.1177/1362361316646558

Imam, M. S., \& Jwaleed, F. E. (2010). Autism from parents' and specialists' perspectives. Oman: House of Culture for Publishing And Distribution.

Imran, N., Chaudry, M., Azeem, M., Bhatti, M., Choudhary, Z., \& Cheema, M. (2011). A survey of autism knowledge and attitudes among the healthcare professionals in Lahore, Pakistan. BMC Pediatrics, 11(1), 107-113.

Jensen, C., Martens, C., Nikolajsen, N., Gregersen, T., Marx, N., Frederiksen, M., \& Hansen, M. (2015). What do the general population know, believe and feel about individuals with autism and schizophrenia: Results from a comparative survey in Denmark. Autism, 20(4), 496-508. doi: 10.1177/1362361315593068

Johnson, P., Porter, K., \& McPherson, I. (2012). Autism knowledge among pre-service teachers specialized in children birth through age five: Implications for health education. American Journal of Health Education, 43(5), 279-287. doi: 10.1080/19325037.2012.10599246

Muhammad, Z., Al-Deen, L., \& Abdul-Muhsin, H.(2013). Knowledge about childhood autism among care providers in Baghdad. Arab Journal of Psychiatry, 24(1), 27-31. doi: 10.12816/0000095

Neni, S., Latif, A. ,Wong, S., \& Lua, P. (2010). Awareness, knowledge and attitudes towards epilepsy among rural populations in East Coast Peninsular Malaysia: A preliminary exploration. Seizure, 19(5), 280-290. doi: 10.1016/j.seizure.2010.04.006

Obeid, R., Daou, N., DeNigris, D., \& Simpson, C. (2015). A cross-cultural comparison of knowledge and stigma associated with autism spectrum disorder among college students in Lebanon and the United States. Journal of Autism and Developmental Disorders, 45(11), 3520-3536. doi: 10.1007/s10803-015-2499-1 
Omer, M. (2011). Autistic children: What do you know about autism disorder? (1st ed.). Jordan, Amman: AlZahran House for Publishing And Distribution.

Rahbar, M.; Ibrahim, K., \& Assassi, P. (2011). Knowledge and attitude of general practitioners regarding autonomy in Karachi, Pakistan. Journal of Autism and Developmental Disorders, 41(4), 465-474. doi: 10.1007/s10803-010-1068-x

Ryan, C. (2013). Disability literacy and attitudes towards autism spectrum disorders (Honors Scholar Thesis). University of Connecticut. $\quad$ Retrieved from https://opencommons.uconn.edu/cgi/viewcontent.cgi?article=1328\&context=srhonors_theses

Sayed Ahmed, S. A. (2012). Sleep problems among children with autism. Egyptian Journal of Psychological Studies, Faculty of Education, Ain Shams University, 22(7), 25-30.

Shamsudin, S., \& Abdul Rahman, S. (2014). A preliminary study: Awareness, knowledge and attitude of people towards children with autism. Proceeding of the Social Sciences Research ICSSR (e-ISBN 978-96711768-7-0) Kota Kinabalu, Sabah, Malaysia.

Shetty, A., \& Rai, B. (2014). Awareness and knowledge of ASDs among primary school teachers in India. International Journal of Health Sciences \& Research, 4(4), 80-85. doi: 10.1016/j.seizure.2008.04.007

Tipton, L., \& Blacher, J. (2014). Brief report: Autism awareness: Views from a campus society. Journal of Autism and Developmental Disorders, 44(2), 477-483. doi:10.1007/s10803-013-1893-9

Yoo, H. (2016). Early detection and intervention of autism spectrum disorder. Hanyang Medical Reviews, 36(1), 4-10. doi: 10.7599/hmr.2016.36.1.4 


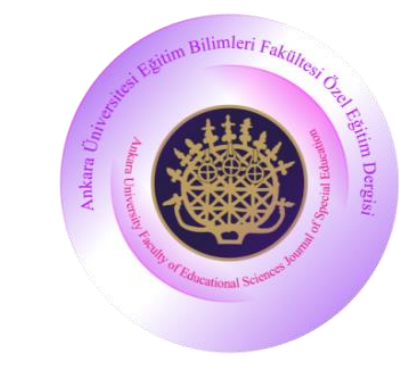

ARAŞTIRMA

\title{
Ankara Üniversitesi Eğitim Bilimleri Fakültesi Özel Eğitim Dergisi
}

\author{
Yıl: 2020, Cilt: 21, Sayı: 2, Sayfa No: 227-246
}

doi: 10.21565/ozelegitimdergisi.513953

\section{Suudi Toplumunda Otizm Spektrum Bozukluğuna İlişkin Farkındalık Düzeyleri: Açımlayıcı/Keşfedici Bir Çalışma}

\author{
Ola M. Abusukkar \\ Princess Nourah Bint Abdulrahman Üniversitesi
}

Öz

Bu çalışmanın amacı Suudi toplumunda otizm spektrum bozukluğuna (OSB) ilişkin farkındalık düzeylerini belirlemektir. Araştırmada, analitik açımlayıcı/keşfedici yaklaşım benimsenmiştir ve OSB farkındalık düzeylerini ölçmek için bir ölçek hazırlanmıştır. Çalışmanın örneklemini yaşları 18 ila 58 arasında değişen 174 erkek ve 714 kadını içeren toplam 888 Suudi oluşturmuştur. Araştırmanın bulguları, katılımcıların \%55.2'sinin OSB'ye ilişkin bilgisinin olmadığını ve \%56.8'i için temel bilgi kaynağının kitle iletişim araçları olduğunu göstermiştir. Farklı bölgelerden gelen katılımcılar arasında OSB farkındalık düzeyleri açısından istatistiksel olarak anlamlı bir fark bulunmamıştır. Erkek ve kadın katılımcılar arasında, kadınların lehine ve genç ve yaşlı katılımcılar arasında ise gençlerin lehine OSB farkındalık düzeylerinde istatistiksel olarak anlamlı farklılıklar ortaya çıkmıştır. En yüksek OSB farkındalık düzeyi doktora eğitimi almış olan en düşük OSB farkındalık düzeyi ise ortaokul ve daha düşük düzeyde eğitim almış olan katılımcılarda görülmüştür. Mesleğe ilişkin olarak, en yüksek OSB farkındalık düzeyi özel eğitim alanında çalışanlarda görülürken en düşük OSB farkındalık düzeyi işsiz katılımcılarda görülmüştür.

Anahtar sözcükler: Otizm spektrum bozukluğu, farkındalık, kitle iletişim araçları, özel eğitim, Suudi toplumu.

Önerilen Atıf Sekli

Abusukkar, O. M. (2020). Suudi toplumunda otizm spektrum bozukluğuna ilişkin farkındalık düzeyleri: Açımlayıcı/Keşfedici bir çalışma. Ankara Üniversitesi Ĕ̆itim Bilimleri Fakültesi Özel Ĕgitim Dergisi, 21(2), 227-246. doi: 10.21565/ozelegitimdergisi.513953

\footnotetext{
*Sorumlu Yazar: Dr. Öğr. Üyesi, E-posta: dr.ola.sukkar@gmail.com, https://orcid.org/0000-0001-7923-1378
} 
Otizm spektrum bozukluğu (OSB), genellikle ilk 2-3 yaş civarında tanılanan yaygın nörogelişimsel bir bozukluktur ve sosyal etkileşim ve iletişimdeki bozukluklar; insanlar, nesneler ve olaylara ilişkin zorluklar ile kısıtll, tekrarlayıcı davranış örüntüleri, ilgiler ve etkinliklerle karakterizedir (American Psychiatric Association, 2013; Hallahan, Kauffman, \& Pullen, 2009; Omer, 2011). Dünya Sağlık Örgütü’nün (World Health Organization, akt., Doha International Family Institute, 2018) de belirttiği gibi 2017'de her 160 çocuktan 1'inin OSB tanısı alması son elli yılda OSB yaygınlığında hızlı bir artış olduğunu göstermektedir. Arap Dünyasındaki ülkelerde yapılan çalışmalarda OSB'nin tanılanmasına ilişin gerçekleştirilen araştırmaların sınırlı sayıda olduğu görülmüştür. Çok ilerleme kaydedilmesine rağmen, Arap Dünyasında OSB araştırmaları çok sınırlı kalmıştır (Hassan, 2019). Lübnan'da OSB sıklığı 66 çocukta 1'dir (Chaaya, Saab, Maalouf, \& Boustany, 2016). Dubai Otizm Merkezinde uygulanan otizm tanı testine göre, otizm Dubai'de ve Umman Sultanlığı'nda görülen her 146 doğumdan 1'ini (\%68) etkilemektedir, başka bir deyişle 10.000 çocuktan 1.4'ünde OSB görülmektedir, erkekler ve kadınlar için oran 1:4'tür (Al-Ansari \& Ahmed, 2013). Suudi Arabistan'da OSB yaygınlı̆ı̆ , devlet istatistiklerine göre \%15 ila \%17 arasında artmıştır (Facilitating Services for Autistics, 2017). Bu istatistiklere göre OSB yaygınlığı önemli ölçüde artmıştır ve OSB aileler için sosyal bir yük haline gelmeye başlamıştır. Bu nedenle, OSB için daha spesifik tanılama süreçlerinin geliştirilmesi, OSB'nin erken teşhisi ve OSB'li çocukların eğitimine katkıda bulunması için erken müdahalelerin geliştirilmesi önemli hususlar haline gelmiş̧ir. Buna karşın, Suudi Arabistan'daki halkın çoğunluğunda bozukluğa ilişkin farkındalık halen sınırlıdır.

Mevcut çalışma, Suudi toplumundaki OSB farkındalık düzeylerini belirlemeyi amaçlamaktadır. Bu araştırmayla Suudi toplumundaki OSB farkındalık düzeylerinin idari bölge, cinsiyet, yaş, akademik nitelik ve mesleğe göre değişip değişmediğinin belirlenmesiyle alanyazındaki bilgi açı̆̆ının doldurulması hedeflenmektedir. $\mathrm{Bu}$ çalışmada şu ana soruya yanıt aranmaya çalışılımıştır: Suudi toplumunda OSB farkındalık düzeyleri nasıldır? $\mathrm{Bu}$ ana soruyla birlikte şu alt sorulara da yanıt aranmıştır: (1) OSB hakkında bilgisi olan Suudi bireylerin yüzdesi nedir? (2) Suudi bireylerin OSB hakkındaki bilgi kaynakları nelerdir? (3) Farklı bölgelerden gelen bireylerin, (4) Kadın ve erkeklerin, (5) Genç ve yaşlı bireylerin, (6) Farklı akademik niteliklere sahip bireylerin ve (7) Farklı meslekleri olan bireylerin OSB Farkındalık Ölçeğinden aldıkları ortalama puanlar arasında istatistiksel olarak anlamlı farklar var mıdır? Bu soruların yanıtlarını araması açısından bu çalışma özel eğitim alanı için önemlidir. Aynı bağlamda yürütülen önceki çalışmalar çok sınırlı olduğundan bu araştırmada, Suudi toplumunda OSB farkındalık düzeylerinin belirlenmesi hedeflenerek alanyazındaki boşluğun doldurulması amaçlanmaktadır. Suudiler arasında OSB farkındalık düzeylerinin yaş, cinsiyet, meslek, akademik yeterlilik ve idari bölge bazında incelenmesi sayesinde bu çalışmanın sonuçları ışığında farkındalık programları geliştirilebilecektir. Bu programlar, topluma otizmin nedenleri, belirtileri, tanı kriterleri ve müdahale yöntemleriyle ilgili çeşitli bilgiler sağlayacaktır. Bu nedenle, bu çalışma Suudi Arabistan'daki birçok vaka için erken teşhis ve müdahaleye yardımcı olacak otizm hakkında sosyal farkındalığın artırılmasına katkıda bulunacaktır. Otizm hakkında sosyal farkındalığın artırılması, OSB'nin erken teşhisinde ve buna bağlı olarak erken müdahale ve uygun müdahale ile gerekli desteklerin sağlanmasında da katkılar sağlayacaktır.

\section{Yöntem}

$\mathrm{Bu}$ araştırmada tanımlayıcı analitik yaklaşım benimsenmiştir. Çalışma örnekleminde 18-58 yaşları arasında, ortalama yaşları 35.33, standart sapması 9.85 olan 174'ü erkek, 714'ü kadın olmak üzere toplam 888 katılımcı yer almıştır. Suudi toplumunda OSB farkındalık düzeylerini belirlemek için yazar tarafından OSB Farkındalık Ölçeği geliştirilmiştir. Ölçeğin alt boyutları, iletişim, sosyal etkileşim, tekrarlayıcı davranışlar ve OSB tabanlı problemlerdir. Ölçek, her alt boyut için 8 madde olmak üzere toplam 32 maddeden oluşmuştur. Üçlü Likert tipi dereceleme ile puanlanan maddeler için 0 (sıfir) "Bilmiyorum", 1 (bir) "Büyük olasılıkla biliyorum" ve 2 (iki) "Biliyorum" olarak puanlanmaktadır. Ölçek toplam puanı 0 ile 64 arasında değişmekte ve ölçekten alınan yüksek puanlar yüksek düzeyde OSB farkındalığına işaret ederken düşük puanlar düşük düzeyde farkındalığı göstermektedir. 


\section{Bulgular ve Tartışma}

Araştırmanın bulguları, katılımcıların otizm hakkında bilgilerinin olmadığını ve düşük düzeyde OSB farkındalıkları olduğunu göstermektedir. Katılımcılar OSB hakkında bilgiyi en çok medyadan aldıklarını belirtmişlerdir. Bu durum OSB'nin, diğer bozukluklardan daha geç keşfedilmiş nörogelişimsel bir bozukluk olmasından kaynaklanıyor olabilir. Suudi Arabistan'da, bu bozukluğa verilen önem, Eğitim Fakültelerinin Özel Eğitim Bölümlerinin otizme ilişkin dersler vermeye başlamasıyla birlikte son 15 yılda artmıştır. Buna ek olarak aynı zamanda Eğitim Bakanlığı bozukluğa ilişkin programlar da oluşturmaya başlamıştır.

Benzer şekilde Özel Eğitim alanında uzmanlaşmamış bireylerin yanı sıra otizmli çocukla bir araya gelmemiş olan bireylerin çoğunun, OSB'ye ilişkin bilgisinin olmadığı belirlenmiştir. Suudi yetkililerin otizme verdiği önemin artmasıyla, bozukluğun tartışılması için birçok bilimsel konferans ve seminerin düzenlenmesi sayesinde, OSB'nin otizmli çocuk üzerindeki olumsuz etkileri ve ilişkili sorunlara olduğu kadar sağllk hizmetleri sunan kişilerin sorunlarına da eğilme firsatı bulunmaya başlandı. Genel olarak kitle iletişim araçları ve özellikle de görsel medya, bozukluğu, uydu kanalları ve sosyal medya tartı̧maları sayesinde uzmanlarla yapılan görüşmeler yoluyla ele almaktadır. Başka bir deyişle, kitle iletişim araçları, özellikle TV kanalları, insanların otizm hakkında farkındalıklarını artırmaya katkıda bulunmuştur. Farklı ekonomik ve sosyal düzeylerden gelen farklı bölgelerde ikamet eden katılımcıların \%56.8'i için medya OSB'ye ilişkin temel bilgi kaynağıdır.

$\mathrm{Bu}$ araştırmanın bulguları farklı bölgelerde yaşayan katılımcıların OSB farkındalığına ilişkin ortalama puanlarında istatistiksel olarak anlamlı bir fark olmadığını göstermektedir. Bu durum, bölgeler arasında bir ayrım yapılmaksızın Suudi Arabistan'da, Krallık çapında, tüm OSB'li bireylere benzer şekilde yaklaşılmasıyla açıklanabilir. Krallıkta'ki tüm Eğitim Fakültelerinin Özel Eğitim Bölümlerinin kurulması bu durumun önemine vurgu yapmaktadır. Kralık'ın tüm bölgelerinde bu alandan sorumlu olanlar, OSB ile ilgili çeşitli sorunları tartışmak üzere konferanslar ve bilimsel seminerler düzenlemeye teşvik edilmektedirler. Suudi halkının otizm farkındalığını artırmak için atölye çalışmaları ve eğitim kursları düzenlenmektedir. Kitle iletişim araçları, özellikle TV kanalları, farklı bölgelerdeki Suudi halkına OSB hakkında bilgi vermektedir (Al-Khashramy, 2003).

OSB farkındalık düzeyleri açısından erkek ve kadın katılımcıların ortalama puanlarında kadınların lehine istatistiksel olarak anlamlı bir fark bulunmuştur. Kadın katılımcılar, OSB hakkında erkek katılımcılardan daha yüksek düzeyde farkındalık göstermişlerdir. Bu durum kadın katılımcılarda kalıtımsal olarak görülen annelik duygularından kaynaklanıyor olabilir, kadınlar otizmli çocuklara karşı daha merhametli ve çocuklara kendilerini daha yakın hissediyor olabilirler (Tipton \& Blacher, 2014). Otizmli çocukların anneleri ve kız kardeşleri onların temel bakıcıları konumundadırlar, bu nedenle de anneler ve kız kardeşler OSB hakkında bilgi arayışına girerler böylece otizmli akrabalarına yardımcı olabilirler. Ayrıca, OSB atölye çalışmalarındaki ve eğitimlerindeki katılımcıların çoğu yine kadınlardan oluşmaktadır ve bu da kadınların OSB hakkındaki bilgi düzeylerinin erkeklerinkinden daha yüksek olmasına neden olmuş olabilir.

OSB farkındalık düzeyleri açısından genç ve yaşlı katılımcıların ortalama puanlarında gençler lehine istatistiksel olarak anlamlı bir fark bulunmuştur. Genel olarak, Arap dünyasında ve özellikle de Suudi Arabistan'da otizme son 20 yılda ciddi bir ilgi başladığı görülmektedir. Bu durum, daha genç bireylerin üniversite yıllarında OSB ile ilgili konferans ve seminerlere katıldığını ve bu nedenle de otizm hakkındaki yüksek düzeyde bilgi elde ettiklerini gösteriyor olabilir. Buna ek olarak, araştırmaya katılan gençler sosyal medyayı yaşlı katılımcılardan daha iyi düzeyde kullanma becerisine sahip olabilirler. Benzer şekilde, daha genç katılımcılar OSB ile ilgili bilgileri yaşça daha büyük katılımcılardan daha hızlı arayabilmekte ve bu bilgilere daha çabuk ulaşabilmektedirler. En yüksek düzeyde OSB farkındalığı doktoralı katılımcılarda görülürken en düşük farkındalık ortaokul ve daha düşük eğitim almış olanlarda görülmüş̧ür. Yüksek lisanslı katılımcılarının ortalama puanları ile diğer katılımcılar karşılaştıııldığında OSB farkındalık düzeylerinde yüksek lisans yapmış olanlar lehine istatistiksel olarak anlamlı farklılıklar bulunmuştur. Lisans mezunu katılımcıların ortalama puanları ile daha düşük eğitim düzeyine sahip katılımcıların OSB farkındalık düzeyleri lisans mezunlarının lehine istatistiksel açıdan $p=.01$ düzeyinde anlamlı şekilde farklılık göstermiştir. Ortaokul mezunu katılımcıların OSB farkındalık düzeyleri ile daha düşük eğitim 
düzeyine sahip bireylerin farkındalık düzeyleri açısından ortaokul mezunlarının lehine istatistiksel açıdan anlamlı fark bulunmuştur $(p=.01)$. Sonuç olarak, en yüksek farkındalığın doktora mezunlarında görüldüğü en düşük farkındalığın ise ortaokul ve daha düşük eğitim düzeyine sahip bireylerde görüldüğü söylenebilir. Bu sonuçlar akademik yeterlikleri yüksek olan katılımcıların daha düşük yeterliğe sahip bireylere göre eğitim kurumlarında daha çok zaman geçirmesiyle açıklanabilir. Buna ek olarak örneğin doktora eğitimi almış bireylerin daha fazla eğitim dersleri verdikleri bu nedenle de OSB de dâhil olmak üzere genel bilgi ve kültür düzeylerinin daha yüksek olduğu söylenebilir. Bu bireyler, üniversiteler tarafından OSB'ye ilişkin verilen seminer, konferans ve çalıştaylara daha fazla katılım göstermiş olabilirler. Bu öğeler bir araya geldiğinde daha yüksek akademik yeterliğe sahip bireylerin OSB farkındalıklarının da daha yüksek olması daha muhtemeldir. Bu sonuçlar, OSB farkındalığının daha yüksek eğitime sahip bireylerde daha yüksek olduğunu gösteren araştırma bulguları ile de tutarlıdır (Dillenburger, Jordan, McKerr, Devine, \& Keenan, 2013; Haimour \& Obaidat, 2013; Tipton \& Blacher, 2014).

Mesleki açıdan, en yüksek OSB farkındalık düzeyinin özel eğitim alanında çalışanlarda en düşük farkındalık düzeyinin ise işsizlerde olduğu görülmüştür. Genel eğitim alanında çalışan katılımcılar ile diğer alanlarda çalışan katılımcılar arasında $p=.01$ düzeyinde istatistiksel açıdan anlamlı farklılıklar bulunmuştur. Tıp alanında çalışan katılımcıların OSB farkındalık düzeyleri genel eğitim alanında çalışan katılımcılardan yüksektir. Genel eğitimde çalışan katılımcılar ile diğer mesleklerden olan ve işsiz katılımcılar arasında genel eğitimde çalışanlar lehine istatistiksel olarak anlamlı farklar vardır. Tıp alanında çalışan katılımcılar ile diğer alanlarda çalışan ve işsiz katılımcılar arasında tıp alanında çalışanlar lehine $p=.01$ düzeyinde istatistiksel olarak anlamlı farklılıklar vardır. Diğer mesleklerden katılımcılar ile işsiz olan katılımcılar arasında $p=.01$ düzeyinde diğer mesleklerden olanlar lehine istatistiksel olarak anlamlı fark vardır.

$\mathrm{Bu}$ araştırmanın sonuçlarına göre özel eğitimde çalışan katılımcıların, diğer mesleklerden ve işsiz olanlar katılımcılardan daha yüksek düzeyde OSB farkındalığı olduğu sonucuna varılabilir. Bu sonuçlar, öğretmenler, sosyal hizmet uzmanları, psikologlar ve dil-konuşma terapistleri gibi özel eğitim alanında çalışan bireylerin üniversite eğitimleri sırasında otizmle ilgili konular üzerine odaklandıklarını gösteriyor olabilir. Üniversite eğitimleri bu bireylerin OSB hakkında bilgilerini yapılandırmalarına yardımcı olmuş olabilir. Ayrıca, otizmli çocuklarla ilgilenmek, OSB farkındalık düzeylerini artırmaya katkıda bulunmuş olabilir. Bu bireylerin bilgileri yalnızca teorik çalışmalardan değil uygulamada otizmli bireylerle etkileşimden de kaynaklanıyor olabilir. $\mathrm{Bu}$ nedenle, bu gruptaki bireylerin OSB farkındalık düzeyleri diğer gruplardan daha yüksektir. OSB'li çocuk sayısındaki artış nedeniyle doktorlar, çocuk doktorları ve psikiyatristler otizmle daha fazla ilgilenmeye başlamışlardır. Kamu ve özel hastanelerde pediatri kliniklerine, psikiyatri kliniklerine ve dil-konuşma kliniklerine gelen otizmli çocukların sayısında hızlı bir artış vardır. Benzer şekilde, OSB'ye ilişkin bilimsel ve tıbbi daha fazla çalışma yapılmaya başlanmıştır. Hemşireler ve sağlık hizmeti verenler, OSB hakkında yüksek düzeyde bilgiye sahiptir, ancak bu bireylerin bilgi düzeyleri özel eğitim alanında çalışanlarınkinden daha düşüktür. Genel eğitim alanında, Eğitim Bakanlığı, birçok devlet okulunda OSB'li öğrencilere akademik entegrasyon sistemi uygulamaya başlamıştır. Bu okullarda çalışan bireyler, otizmli öğrencilerle yakından ilgilenme firsatı bulabilmekte OSB'ye ilişkin daha fazla bilgi edinebilmektedirler. Bu nedenle bu bireyler diğer mesleklerde çalışan ve işsiz olanlardan daha yüksek düzeyde OSB farkındalığına sahiptirler. Diğer mesleklerde çalışan kişiler ise OSB programlarını içeren özel eğitim veya genel eğitim okullarında çalışan bazı kişilerle veya OSB'li bireylere tıp ve sağlık hizmeti sunan kişilerle sosyal olarak etkileşime girme firsatı bulmaktadırlar. Bu durum bu bireylerin OSB hakkında bilgi edinmelerine yardımcı olmakta bu nedenle de bu bireylerin OSB farkındalıkları işsizlerden daha yüksek düzeyde olmaktadır.

\section{Sonuc}

Otizm, sosyal etkileşimdeki, sözlü ve sözlü olmayan iletişimdeki bozulmalar ve tekrarlayan davranışlarla karakterize nörogelişimsel bir bozukluktur. Otizmin geniş bir spektrumda ortaya çıkması, her otizmli bireyin bozukluktan farklı şekilde etkilendiği ve spektrumdaki yerine bağlı olarak farklı özelliklere sahip olduğu anlamına gelir. Bu çalışma Suudi toplumundaki bireylerin otizm farkındalık düzeylerinin cinsiyet, yaş, akademik yeterlilik ve meslek değişkenlerine göre belirlenmesini amaçlamaktadır. Katılımcıların \%44.8'inin OSB hakkında bilgi 
sahibiyken \%55.2'sinin OSB hakkında bilgi sahibi olmadığı sonucuna varılmıştır. Kitle iletişim araçları, katılımcıların \%56.8'inin temel bilgi kaynağıdır. Erkek ve kadın katılımcılar açısından, kadın katılımcıların lehine; genç ve yaşlı katılımcılar açısından genç katılımcıların lehine OSB farkındalık düzeyleri açısından istatistiksel olarak anlamlı farklılıklar bulunmuştur. En yüksek OSB farkındalık düzeyi doktora mezunlarında, en düşük farkındalık düzeyleri ise ortaokul ve daha düşük eğitim seviyesine sahip olanlarda görülmüştür. Meslekler açısından, en yüksek OSB farkındalık düzeylerinin özel eğitim alanında çalışanlarda görülürken en düşük farkındalık düzeyleri işsizlerde görülmüştür. OSB'nin nedenlerine ilişkin kesin açıklamalar olmasa da erken uygun müdahalenin OSB'li bireylerin becerilerini ve iletişim yeterliliklerini geliştirmede etkili olduğu kanıtlanmıştır. OSB ile ilgili sosyal farkındalığın artırılmasının bozukluğun erken teşhis edilmesine ve uygun müdahalenin sağlanmasına katkıda bulunduğu inkâr edilemez. Ayrıca, bu durum OSB'li çocuğun ailesine gerekli hizmetlerin ve desteğin sunulmasına yardımcı olur. Bu nedenle, OSB'ye ilişkin sosyal farkındalığı artırmak otizmli çocuk, çocuğun ailesi, öğretmenler, sağlık hizmeti sağlayanlar ve nihayetinde tüm toplumun yararına olacaktır. 